PRZEGLĄD RUSYCYSTYCZNY 2021, $\mathrm{nr} 1$ (173)

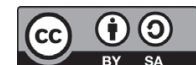

DOI 10.31261/pr.9116

\author{
NADEZHDA MOROZOVA (НАДЕЖДА МОРОЗОВА) \\ Институт литовского языка (Вильнюс, Литва) \\ (D) ORCID ID 0000-0002-1228-6021
}

\title{
К ВОПРОСУ О СТАРОВЕРАХ-ФИЛИППОВЦАХ В СЕВЕРНОЙ ДОБРУДЖЕ: КИТЕЛЕШТСКАЯ ПУСТЫНЬ
}

ABOUT OLD BELIEVERS FILIPPIANS IN NORTHERN DOBRUJA: KITELESHT MONASTERY

Russian Old Believers Popovtsy (Lipovans) are well-known in Romania. At the same time, there are no reliable information about Priestless Filippians (bespopovtsy) in this country. The aim of this article is basing on Filippians' sources and Romanian historical and local history investigations to put new information concerning the existence of the Priestless Filippians monastery in Northern Dobrudja in the second half of the 19th century. The study is based on comparative, descriptive, interpretative and other research methods.

Several Filippians' manuscripts mention the previously unknown Kitelesht monastery (hermitage), located "beyond the Danube. "The data, presented in Filippians' documents and Romanian studies and reference books, allow us to identify the "Kitelesht hermitage" with the small Russian Priestless monastery in Tichilești on the right bank of the Danube in Tulcea County (județ). At the moment we have information about 12 inhabitants of this monastery, who lived there at different times, apparently from the mid-1850s to the end (or at least until the middle) of the 1870s. At the beginning of the 20th century the monastery in Tichilești ceased to exist, and some years later in this place a leper colony was founded.

Keywords: Old Believers, Priestless Old Believers, Filippians, Kitelesht monastery, Romania, Tichilești

Филипповское согласие - одно из самых консервативных направлений в беспоповском староверии, возникшее в Поморье в конце 1730-х гг. в связи с отказом части поморцев (выговцев) признать и принять в качестве богослужебной практики так называемое богомолие за государя, которое должны были совершать все подданные Российской империи. Чтобы не вводить молитвы за императрицу, часть выговских насельников призывала к самосожжению. В этих спорах победило умеренное крыло, желавшее сохранить обитель: руководители пустыни вынужденно отказались от догмата немоления и в 1739 г. ввели в богослужение молитвы за царствующую императрицу. Это решение стало причиной раскола в поморском согласии. Про- 
тивники «царского богомолия» во главе со старцем Филиппом (1672-1742; в миру - бывший беглый солдат Фотий Васильев) покинули общежительство, образовав новое, филипповское, согласие. Хотя Филипп вместе со своими сторонниками сгорел в 1742 г., его основные идеи нашли многочисленных сторонников сначала в Поморье, а затем и в других регионах России.

Филипповское согласие считается преимущественно российским явлением. И хотя в научной и научно-популярной литературе по истории староверия иногда встречаются указания на то, что в последней трети XVIII-XIX в. филипповские общины появились в Польше и Румынии, конкретных сведений об этих поселениях там, как правило, не приводится ${ }^{1}$. По мнению Василия Волкова, староверы-филипповцы могли оказаться на территории Речи Посполитой после предпринятой ими в 1765 г. попытки захвата Зеленецкого монастыря (Новгородская епархия) и последовавшей за этим гарью². Эту точку зрения разделяет Андрей Горбацкий ${ }^{3}$ хотя, как и Волков, не подтверждает ее конкретными примерами. Безусловно, отдельные представители этого толка действительно могли жить в приграничных с Российской империей регионах, однако вполне вероятно, что глухие упоминания о беспоповцах-филипповцах за границей Российской империи могут быть связаны и с другими причинами, о чем несколько ниже. В дальнейшем попытаемся разобраться, что могут означать эти осторожные замечания о филипповцах в Румынии в различных вторичных источниках.

Цель настоящей статьи - на основе анализа внешних (нестарообрядческих) исторических документов и сочинений выяснить причины возможной терминологической омонимии (филипповцы/филиппоны (липоване) как наименование раз-

1 К.Я. Кожурин, Духовные учителя сокровенной Руси, Питер, Санкт-Петербург 2007, с. 260-261; В.И. Щипин, Старообрядчество в верхнем течении Северной Двины, Лабиринт, Москва 2003, с. XX; и др.

2 В. Волков, Сведения о начале, распространении и разделении раскола и о расколе в Витебской губернии, В типографии губернскаго правления, Витебск 1866, с. 50. О захвате Зеленецкого монастыря см.: РГИА, ф. 796, оп. 46, д. 160 (По доношению синодальнаго члена преосвященнаго Димитрия митрополита Новгородскаго о произошедших от потаенных раскольников приходом в Зеленецкий монастырь наглых и озорнических поступках (1765). Благодарю К.Я. Кожурина за возможность познакомиться с материалами этого дела.

3 А.А. Горбацкий, Старообрядчество на белорусских землях, Брест 2004, c. 80 . 
личных групп и согласий староверов), иногда приводящей к необоснованным утверждениям о присутствии той или иной группы староверов в отдельных регионах, а также, опираясь на собственно филипповские рукописные источники и румынские историко-краеведческие материалы, ввести в научный оборот новые данные о присутствии филипповцев-беспоповцев на территории современной Румынии. В работе использованы сравнительный, описательный, интерпретационный и др. методы исследования.

\section{Филипповцы и/или Филиппоны (пилипоны): К ВОПРОСУ О ТЕРМИНОЛОГИИ}

Исследователям и знатокам староверия хорошо известно, что наименование с корнем Филипп- могло применяться к различным группам последователей старого обряда: это как филипповцы-беспоповцы, так и филипоны/пилипоны (филиппоны), филипповане, липоване поповцы или даже староверы вообще. Однако значительно реже упоминается о том, что в некоторых источниках конца XVII - первой трети XVIII в. встречается термин филипповцы (а также польск. filipowcy и лат. Philippoviani), традиционно соотносимый с беспоповским согласием, в отношении староверов ветковско-стародубского региона. Приведем несколько примеров из документов на разных языках.

Впервые термин филипповцы фиксируется, очевидно, в послании секретаря короля Яна III Собеского Петра Полтьева (Piotr Michał Polttiew) об окончательном решении судебного дела между могилевскими дворянами Карлом Халецким и Томашем Красинским, написанном 21 февраля 1690 г. на польском языке. Полтьев писал, что на его вопрос о том, «что вы за люди и откуда прибыли», ветковские староверы ответили, что они «православные русские люди», москали, а филипповцами их называют потому, что некий «простой человек» Филипп из-под Стародуба оказывал содействие в их расселении по окрестным слободам, ср.:

De genere gdym się pital, skąd by byli ludzie przybyli [...]. A ze nas zowią Filypowcami, tedy to niesłusznie iest, żebśmy od Filipa iakiego pochodzili, tylko to iest ztąd, yż nieiakj Filip prosty człowiek pod Starodubem był osadcą na Siewierzu y on naszych braci moskalów osadził na niektórych słobodach y od tego 
osadczego poczęli lud się zwać Filipowcami, a myśmy są prawosltawni Ruscy ludzie ${ }^{4}$

Униатский историк и богослов Игнатий Кульчинский (Ignacy Kulczyńsky; 1694-1747) в работе Specimen Ecclesiae Ruthenicae... (Идеал Русской церкви...), изданной в Риме в 1733 г., в разделе, посвященном патриарху Никону, писал о бежавших от последовавших после никоновских реформ репрессий и преследований («наказывали огнем и мечем») из Московии в Белую Русь $\oint u-$ липповианах, названных так по имени их предводителя некоего Филиппа:

Correxerat jam Nicon sacros libros, probantibus talem correctionem episcopis moscoviticis; sed acto ipso in exilium, magna pars cleri tum saecularis, tum regularis rejecit hosce libros, dictitans multis erroribus eos scatere: unde accedente plebe crevit ingens schisma, cujus asseclae quodam Philippo antesignano dicti fuere Philippoviani. Animadversum in eos igne ac ferro, sed hisce nil proficientibus, pulsi omnes ex ditionibus Moscoviae, in quibusdam albae Russiae locis domicilia fixere ${ }^{5}$.

Наконец, одесский историк Юрий Горбунов обратил внимание, что в Обличении неправды раскольнической Феофилакта Лопатинского, подготовленном по поручению Синода в 1723 г., но изданном лишь в 1745 г. уже после смерти автора, также упоминается некий простолюдин Филип, распространявший древлеправославие среди малороссиян: «Ересь $\Phi и-$ липовцы, наченшееся от простолюдина Филипа в Стародубъе, и привождаше малоросиян в раскольническое крещение, и православные христиане начаша их называти Филиповцами

4 Д.И. Довгялло, Могилевская старина. К истории Ветки. Документ 1690 года // Е.Р. Романов (ред.), Могилевская старина: Сборник статей «Могилевских губернских ведомостей», вып. 1: 1898 и 1899 г2., Типография Губернскаго правления, Могилев Губернский 1900, с. 4 (10-го счета) (курсив мой - Н. М.). Анализ документа (и его перепечатку) см.: Г. Поташенко, Cmaроверие в Литве: Вторая половина XVII - начало XIX вв. Исследования, документы, материалы, Aidai, Вильнюс 2006, с. 250-251, 288-291, 312-313.

5 Цит. по изд.: Specimen Ecclesiae Ruthenicae: ab origine susceptae fidei ad nostra usque tempora in suis capitibus seu primatibus Russiae cum S. Sede Apostolica Romana semper unitae per Ignatium Kulczynski, Lethielleux, Parisiis 1859, c. 135 (курсив мой - Н. М.). Впервые на этот источник обратил внимание, кажется, В. Якубовский, см.: W. Jakubowskij, Z historii kolonii staroobrzędowców rosyjskch na Mazurach, „Slavia Orientalis“, 1961, vol. X(1), s. 84. Благодарю А. Земкаюте и М. Чюринскаса за помощь в переводе этого фрагмента. 
и доднесь» ${ }^{6}$. Александр Пригарин, комментируя указанные сведения Горбунова, пишет, правда, без ссылок на источники, что этот Филипп агитировал староверов с Ветки переселяться в юго-западном направлении, в Бессарабию, ближе к Ясскому митрополиту․

Список источников, в которых упоминается ветковско-стародубский Филипn, а также ветковско-стародубские филипповцы, можно продолжить: это судебные дела, униатские и иезуитские сочинения и письма и др.

Как видим, эти свидетельства датируются 1690 - началом 1730-х гг., т.е. значительно более ранним периодом, чем оформление и выделение филипповского беспоповского согласия, а сам термин появляется в Речи Посполитой сначала в польскоязычных источниках (что неоднократно отмечалось в историографии). Ветковские филипповцы/филипповиане/ филипоны в дальнейшем в результате печально известных выгонок 1735 и 1764 гг. и по другим причинам были вынуждены покидать обжитые места и уходить в поисках более спокойного места жительства, унося с собой и данное им наименование, которое в разных странах с течением времени под влиянием языковых и иных причин несколько видоизменилось ${ }^{8}$. Часть вет-

${ }^{6}$ [Феофилакт (Лопатинский)], Обличение неправды раскольнической, Синодальная типография, Москва 1745, л. 4 (прилож.); цит. по: Ю.Е. Горбунов, К вопросу о происхождении названия «липоване»// Археологія та етнологія Східної Європи: матеріали і дослідження, Астропринт, Одеса 2000, с. 141 (курсив мой - Н. М.).

7 А.А. Пригарин, Русские старообрядиы на Дунае. Формирование этноконфессиональной общности в конце XVIII - первой половине XIX вв., Смил Археодоксия, Одесса-Измаил-Москва 2010, с. 38.

8 Об особенностях употребления различных словообразовательных и фонетических вариантов термина с корнем Филипп- в историографии разных стран и попытках его этимологизации см., напр.: Ю. Е. Горбунов, К вопросу о происхождении..., с. 135-144; Ф.И. Кирилэ, О генезисе этнонима «Русские липоване» // В.И. Осипов и др. (сост.), Старообрядчество. История. Культура. Современность. Материалы, Москва 2007, т. 2, с. 104-117; В.А. Липинская, Этнонимы и конфессионимы русского населения в Румынии, „Этнографическое обозрение" 1998, № 5, с. 44-58; Г. Поташенко, Староверие в Литве..., c. 252, 312; Библиография работ по названиям и самоназваниям старообрядиев северо-западного Причерноморья, 2016, http://eurasianphonology. info/static/groups/biblio.html (18.05.2020); E. Iwaniec, $Z$ dziejów staroobrzędowców na ziemiach polskich XVII-XX w., Państwowe Wydawnictwo Naukowe, Warszawa 1977, s. 79-80; I. Munteanu, Monografia rușilor lipoveni din Brăila. Pescuitul, activitate tradițională, Proilavia, Brăila 2015, c. 74-96; S. Pastuszew- 
ковцев (преимущественно староверы-поповцы) действительно отправилась на юго-запад и, минуя несколько промежуточных пунктов, осела в Буковине, Подолье, Бессарабии и низовьях Дуная. Это обстоятельство объясняет причины появления и происхождение термина филиппоны/пилипоны как в официальных польских (времен Речи Посполитой), так и прусских, австровенгерских, а также некоторых российских (касающихся старообрядцев западных окраин империи) источниках, причем часто это наименование применялось ко всем староверам, независимо от их толка и территории исхода, т.е. по сути было синонимом определения староверы. А поскольку какое-то количество представителей филипповского беспоповского согласия (тоже филипповцев) все же проживало на исторических землях Речи Посполитой, в Пруссии 9 и, видимо, в др. странах, это обстоятельство породило терминологическую омонимию и, как следствие, некоторую путаницу при интерпретации данных первоисточников $^{10}$, которая иногда наблюдается как в научной, так и научнопопулярной литературе.

\section{«КИТЕЛЕШТСКАЯ ПУСТЫНЯ": ДАННЫЕ ФИЛИППОВСКИХ ИСТОЧНИКОВ}

Далее обратимся к собственно румынской ситуации и попытаемся выяснить, были ли филипповцы-беспоповцы на территории современной Румынии или упоминание о них во вторичных

ski, Przegląd źródet i opracowań do badań staroprawosławia, Instytut Wydawniczy „Świadectwo”, Bydgoszcz 2016; и др.

9 См., напр.: Состояние старообрядческаго раскола и православной миссии среди него за 1909 2., „Полоцкие епархиальные ведомости” 1911, № 17, с. 343; E. Iwaniec, $Z$ dziejów staroobrzędowców..., s. 79-82; и др. Об одном филипповце, проживавшем в середине XIX в. в Войновском монастыре в Пруссии, упоминал Павел Прусский: «А когда приехал в Пруссию, в обитель, нашел одного филипповца, пребывавшего в обители, за неимением филипповской, отца Елеозара, горячего филипповского ревнителя» (Полное собрание сочинений Никольскаго единоверческаго монастыря настоятеля архимандрита Павла, Типография Э. Лисснера и Ю. Романа, Москва 1897, т. 1, с. 2).

${ }^{10}$ Очевидно, некритическим отношением к источникам следует объяснять данные А.А. Горбацкого, идущего здесь вслед за В. Волковым (В. Волков, Сведения о начале, распространении и разделении раскола..., с. 35, 47, 50), о значительном количестве филипповцев-беспоповцев в XIX в. на территории современной Беларуси (А.А. Горбацкий, Старообрядчество на белорусских землях..., с. 132 и др.). 
источниках - это следствие показанной выше терминологической омонимии.

О филипонах/липованах, т.е. поповцах, проживающих на территории современной Румынии, хорошо известно: описаны направления миграции и история формирования основных центров, география распространения, особенности традиционного говора и религиозной духовной культуры и др., см., напр., монографию Александра Пригарина ${ }^{11}$ со ссылками на источники и литературу по истории вопроса. В то же время исследований о филипповцах-беспоповцах на территории этой страны в прошлом и настоящем практически нет, за исключением небольшого предварительного обзора Алексея Безгодова, посвященного современному состоянию румынского беспоповства ${ }^{12}$. Новые материалы, недавно обнаруженные в нескольких филипповских рукописях, как кажется, позволяют уточнить «глухие» намеки предыдущих работ и говорить о наличии в Северной (румынской) Добрудже по меньшей мере одной филипповской беспоповской общины более определенно.

Как удалось установить, в нескольких старообрядческих сочинениях упоминается некий филипповский Килештский скит «за Дунаем». Одним из таких памятников является «Родословие иноческаго пострижения, со времени благочестиваго епископа Павла Коломенскаго, сиречь от лета $7164^{\text {го }}$ (1656) [...] и по настоящее 7387 (1879) год, еже от плотскаго воплощения Бога слова 1879 год» (нач.: «Павел, епископ Коломенский, с Игнатием, черным дияконом и еклисиархом Соловецкаго монастыря, постригли Генадиа Каньгина...»), составленное в 1879 г. северодвин-

${ }^{11}$ А.А. Пригарин, Русские старообрядцы на Дунае....

${ }_{12}$ А.А. Безгодов, Староверы-беспоповцы Придунавъя (краткий обзор согласий) // Липоване, Одесса 2004, вып. I, с. 60-63. Н.И. Надеждин сообщает о двух поселениях филиппонов-беспоповцев, приехавших из Пруссии, в окрестностях Галаца (рум. Galaţi) и Васлуй (рум. Vaslui), см.: [Н.И. Надеждин], О заграничных раскольниках, Надеждина (1846) // В. И. Кельсиев (сост.), Сборник правительственньх сведений о раскольниках, Trübner \& $\mathrm{C}^{\circ}$, Лондон, 1860, вып. 1, с. 113. Но здесь, очевидно, речь идет не о филипповцах, а о федосеевцах, так как в Пруссии, по сведениям Павла Прусского, того же Надеждина и других источников, филипповцев практически не было. О беспоповцах в «турецкой» части современной Румынии Надеждин умалчивает. О филипповцах-беспоповцах не знал и П. Сырку, см.: П. Сырку, Наши раскольники в Румынии и отношение к ним румынскаго правительства, „Христианское чтение” 1878, № 5-6, с. 663-705. 
ским книжником Стефаном Фроловым (в иночестве - Сергий Кокшеньгский; † 22.01.1880 $)^{13}$. В нем представлены две линии иноческого пострижения филипповцев: первая берет начало от епископа Павла Коломенского, родоначальником второй был некий инок из рода Севастьяновых из Весьегонского уезда Тверской губернии. На данный момент известно три списка этого сочинения последней четверти XIX - 1910-х (?) гг.: ИРЛИ, собр. Ф.А. Каликина, № 52 (л. 1-5) $)^{14}$; БАН, собр. Ф.А. Каликина, № 109 (л. 371-373) $)^{15}$ и БВАНЛ, F19-331 (с. 307-310) ${ }^{16}$.

В Севастьяновской части Родословия... неоднократно упоминается Кителешская (Кителештская) «пустыня», находящаяся «за границею». Кроме фроловского Родословия... Кителештский скит называется только в сочинениях известного северодвинского филипповского наставника и книжника Симеона Гаврилова (1842-1930-е гг.; в миру - Иван Гаврилович Квашнин) и в кратком анонимном «Показании потомственнаго велекущагося от древняго благочестия пострежения (!) иноческаго чина и предподающагося благословения приемной

13 О Стефане Фролове, его творческом наследии и методах работы с источниками см.: Е.М. Юхименко, К вопросу о книжной основе старообрядческой культуры. Неизвестный филипповский начетчик старец Сергий Кокшеньгский // Ю.С. Белянкин, Е. В. Воронцова, Н. В. Литвина (сост.), Язык, книга и традиционная культура позднего русского Средневековъя в науке, музейной и библиотечной работе: труды IV Международной научной конференции, Изд-во Московского университета, Москва 2019, с. 604-615.

${ }_{14}$ Рукопись в $4^{\circ}, 25$ лл., переписана полууставом северодвинским книжником М.М. Останиным в 1879 г. Подробнее см.: Е. М. Юхименко, «Изыскание о иноческом пострижении» (Филипповское сочинение 6о-х г2. ХІХ в.) // А.Х. Элерт (ред.), Традиции русской духовной культуры в памятниках $X V I-X X$ в., Новосибирск 2018, с. 170.

15 Рукопись в $4^{\circ}, 403$ (I+402) лл., не ранее ноября 1911 г. (в сочинении упоминается газета Новое время от 11 ноября 1911 г.), писана полууставом. Видимо, это автограф петербургского старовера-филипповца Максима Яковлева.

${ }^{16}$ Сборник-конволют в $4^{\circ}, 188$ (I+187) лл. (I л.+374 с.), писан полууставом и гражданской скорописью нескольких почерков; составлен в середине 1880-х гг., видимо, в Москве на Братском дворе. Подробнее см.: Н. Морозова, Рукописный сборник соборных постановлений и других сочинений филипповцев в собрании Библиотеки им. Врублевских АН Литвы, „Slavistica Vilnensis" 2019, Vol. 64(1), c. 87-103, https://www.journals.vu.lt/slavisticavilnensis/article/view/15018 (10.05.2020). Публикацию текста Родословия... по вильнюсскому списку см.: Н. Морозова, Филипповское родословие из рукописного собрания Библиотеки им. Врублевских Академии наук Литвы: источниковедческий анализ, «Известия Уральского федерального университета. Cер. 2: Гуманитарные науки» 2020, т. 22, № 3 (200), с. 72-88, DOI 10.15826/izv2.2020.22.3.045 (23.10.2020). 
друг другу и по днесь» ${ }^{17}$. Владимир Щипин предположил, что Кителештская пустынь - это филипповский скит в Тикелешти, селении в Румынии в низовьях Дуная, которое Гаврилов ошибочно называл Кителешти, но никакой аргументации в пользу такого отождествления, а также каких-либо других сведений об этом ските не привел ${ }^{18}$. Однако поскольку Родословие... Фролова и Показание... возникают независимо от генеалогических разысканий и других сочинений Симеона Гаврилова и в них также фиксируется название Кителешти, становится очевидным, что гавриловское Кителешти - это не случайная ошибка, как считал Щипин, а вполне устойчивая традиция.

В упомянутом сочинении Фролова имеются важные (и, на данный момент, уникальные) сведения о Кителештском ските. Так, Фролов сообщает, что основателем этого скита был некий инок Марк, «уроженец из Корел», которого постриг «изрядный иконописец» Феофан ${ }^{19}$. Инок Марк, в свою очередь, в Кителештской пустыни постриг Иова, Владимира, Боголепа, Афанасия, Макария «и прочих». В авторской редакции Фролова также сказано, что Макарий и Иринарх, также кореляки и постриженики Феофана, около полугода жили в Кителешти, а потом вернулись в Москву, после чего уклонились в единоверие. Постригли ли они кого-нибудь, будучи за границей, неизвестно, однако Фролов среди пострижеников Макария (до его перехода в единоверие) упоминает некоего Антония, «живоущаго за границею» (на момент написания родословия, т.е. в 1879 г. - Н. М.), очевидно, в том же Кителештском ските, а также Варсонофия, жившего за «границей в" Кителешской п8стынь, а нынь в" льто ¥3ТПЗ <7387 / $1879>$ жив8щаго в" Москвђ в" Братскомъ домъ ${ }^{20}$. В Показании... сказано, что инок «Макарїи постриже инока Варсанофї̈ Донскаго въ льто ¥3ТПВ <7382 / 1875> мъсеца декобрА (!) КА <21> днА, благословънїА же сподобленъ отцомъ Іовамъ, п8стыножителемъ скита Кительшты въ Т8рцыи» ${ }^{21}$.

${ }_{17}$ РГБ, собр. Братства Петра митрополита (ф. 579), № 58, л. 3. Рукопись датируется второй половиной XIX в., писана полууставом одного почерка.

${ }^{18}$ В.И. Щипин, Жизнь и труды старца Симеона Северодвинского // В. И. Щипин (публ., предисл. и коммент.), Житие Герасима Вощикова: из истории филипповского согласия (Сочинение старца Симеона Гаврилова), Старообрядческое издательство «Третий Рим», Москва 2010, с. 5.

${ }^{19}$ БВАНЛ, F19-331, с. 309-310; ИРЛИ, собр. Ф.А. Каликина, № 52, л. 3 об.

${ }^{20}$ ИРЛИ, собр. Ф.А. Каликина, № 52, л. 5.

${ }^{21}$ РГБ, собр. Братства Петра митрополита (ф. 579), № 58, л. 3 об. 
Некоторые из упомянутых Фроловым насельников Кителештской пустыни отождествляются достаточно легко. Так, инок Варсонофий Донской известен и по другим филипповским источникам: он был участником собора в дер. Поповка 9 сентября 1881 г. (его имя обычно указывается первым среди сигнатариев соборных решений), он же упоминается в решении Кимрского собора 14 сентября 1894 г. как один из активистов профедосеевской группировки Братского двора, подлежащих отлучению 22. «Варсонофий с Дону» вместе с «Варсонофием другим» участвовал в полемике филипповцев и федосеевцев на Преображенском кладбище в феврале 1906 г. ${ }^{23}$ Подпись «старца Макария» находим, напр., под решениями Московского филипповского собора 18 сентября 1872 г. $^{24}$

Сложнее идентифицировать основателя Кителештского скита инока Марка. Из текста Родословия... непонятно, что скрывается за определением «корляк» / «уроженец из Корел»: речь идет о так наз. тверских корелах (откуда родом некий инок «по фамилии Севастьяновых», от которого и пошла эта ветвь филипповского иноческого пострижения) или о беломорских карелах, где тоже было немало филипповцев, а на севере современной Карелии находился знаменитый Топозерский филипповский скит. Кроме того, в этом фрагменте Родословия... нет и какихлибо уточняющих хронологических примет. На северные земли указывает замечание Фролова, что постриженики Феофана, иноки Макарий и Иринарх, так же, как и Марк, «уроженцы из Корел», до переезда в Москву, а затем в Кителешти, «жили в Поморье богоподвижно ${ }^{25}$. Если это так, то теоретически, с некоторой осторожностью инока Марка можно отождествлять с Марком Топозерским, автором знаменитого Путешественника

${ }_{22}^{22}$ БАН, собр. Ф.А. Каликина, № 107, л. 245, 248 об.; БВАНЛ, F19-331, с. 201.

${ }_{23}$ Т.В. Игнатова, К истории московского филипповского центра Братский двор во второй половине XIX - начале XX вв. (новые документы из фондов ЦИАМ) // Старообрядчество: история, культура, современность, вып. 13, Москва 2009, с. 61. «Варсонофий другой» - наставник Братского двора Василий/Прокопий Фомич Шестаков, принявший постриг с именем Варсонофий в 1900 г. (см.: В.П. Бударагин, «А красок и туши с книгами пошли...» (Переписка северодвинских крестьян-старообрядиев XX в.) // В.Е. Багно (отв. ред.), Пути и миражи русской культуры, Северо-Запад, Санкт-Петербург 1994, с. 364-365, 368 и др.).

${ }^{24}$ См.: БВАНЛ, F19-331, с. 166.

${ }^{25}$ ИРЛИ, собр. Ф.А. Каликина, № 52, л. 4. 
в Беловодье. Если учесть уточнение Юрия Рыкова, что первая редакция Путешественника возникла не ранее $1823 \Gamma^{26}{ }^{26}$, вероятность того, что инок Марк Топозерский (учитывая его склонность к путешествиям) в 1850-х гг. мог оказаться за Дунаем, не представляется столь невероятной. Однако это предположение требует дополнительных разысканий.

Кроме того, как уже говорилось, в Кителешти жил Симеон Гаврилов, причем провел там около четырех лет: приблизительно с 1870 по 1874 гг. В одном из сборников материалов на обороте 5-го ненумерованного листа Симеон Гаврилов поместил краткую выписку о важнейших событиях своей жизни, где среди прочего отметил, что «4 года был за границей съ $¥ 3 Т О И ~<7378$ / $1870>{ }^{27}$. Под указанием «за границей», видимо, подразумевался Кителештский скит. В той же рукописи на л. 195-198 Симеон Гаврилов привел письмо Леонтия Гаврилова 1876 г. «о отщепенцах, живущих за Дунаем», предварив его следующей справкой:

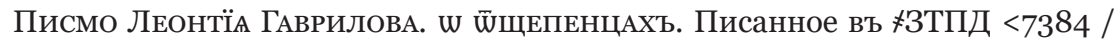
1876> года $w$ ш̈щепенцах. Которои жилъ за Д8наемъ въ скит8 Кителештахъ четырь года и по выход8 в" Москв8 писалъ сїе письмо хр ии>стїАнскї̈А ц<е>рквђ оучителю Владимир8 Терентьевичю ${ }^{28}$ о ш̈щепенцах, жив8щих за Д8наемъ в" городе Т8льчь в" мъстьчькь, называемъм Махм8де ${ }^{29}$. А ш̈щепенцы произошли ше согласї Аристовых, а Аристовы произошли ш̄ согласїА өеодшсїевыхъ.

${ }^{26}$ Ю.Д. Рыков, Ярославский список «Путешественника» Марка Топозерского // Н.В. Абросимова (ред.), Книжная культура Ярославского края 2014: сборник статей и материалов, Издательское бюро «ВНД», Ярославль 2015, с. 37-38. Биографические данные о Марке Топозерском неизвестны. К.В. Чистов, к примеру, даже склонен считать его скорее легендарным персонажем, чем реальным историческим лицом (К. В. Чистов, Легенда о Беловодъе // В.Я. Евсеев, Э.Г. Карху (отв. ред.), Вопросы литературы и народного творчества: сб. ст., Карельское книжное изд-во, Петрозаводск 1962, c. 144-145).

${ }^{27}$ БАН, собр. В. Г. Дружинина, № 846, автограф С. Гаврилова, нач. ХХ в., 402 л. Пользуясь случаем, искренне благодарю М.В. Першину (Новосибирск) и М.В. Корогодину (Санкт-Петербург) за информацию об этой рукописи.

${ }^{28}$ Владимир Терентьевич (Терентьев) - авторитетный северодвинский книжник, соавтор Стефана Фролова, участник нескольких филипповских соборов и «публичного разглагольствия» о браках с Павлом Прусским в 1861 г., см.: БАН, собр. Г. В. Дружинина, № 846, л. 199; ИРЛИ, собр. Ф.А. Каликина, № 52, л. 6 об.-7. Владимир Терентьев умер не позднее 1915 г., см.: Е. М. Юхименко, «Изыскание о иноческом пострижении»..., с. 169.

${ }^{29}$ Махмудия (рум. Mahmudia) - деревня на правом берегу Дуная в жудеце Тульча. 
На полях в правом верхнем углу дополнительно сказано: «Замъчание: Леонтїи Гаврилов выехал из скита Кителешть изза Д8наА ұ3ТПГ <7383 / 1875> года в мае м<еся>ць $»^{30}$. Как видим, Леонтий Гаврилов также провел 4 года в скиту в Кителешти.

Таким образом, учитывая данные перечисленных выше рукописных источников, у нас имеются сведения не только о существовании филипповского скита «за границей», но и по меньшей мере о 12 его насельниках, живших там в разное время, видимо, приблизительно с середины 1850-х до конца (или, по крайней мере, до середины) 1870-х гг.

\section{КИТЕЛЕШТ(И) VS ТИКИЛЕШТИ, ИЛИ ГДЕ НАХОДИЛСЯ ФИлИППОВСКИЙ СКИт}

Следующие вопросы, которые неизбежно возникают при анализе сведений о Кителештском ските, - это его местонахождение и возможность верификации известий, выявленных в рукописных филипповских источниках. Иначе говоря, можно ли на основании имеющихся материалов указать конкретное место, где была расположена обитель, и есть ли какие-либо сведения о ней в других источниках или приведенные выше свидетельства собственно филипповских рукописных памятников уникальны?

Симеон Гаврилов указал, что этот скит расположен «за Дунаем», за границей Российской империи, а анонимный автор Показания... уточнил, что обитель находится «в Турции», т.е. в той части современной Румынии (румынской Добруджи), которая до 1 июля 1878 г. принадлежала Османской империи. Упоминаемый город Тульча как центр отщепенцев-аристовцев недвусмысленно указывает на известный старообрядческий регион в Добрудже между Тульчей (рум. Tulcea) и Брэилой (рум. Brăila) на территории современной Румынии. Изучение современных и исторических карт и географических справочников указанного региона показало, что населенного пункта под названием Кителешти там не было и нет, зато были обнаружены три поселения с названием Тикилешти (рум. Tichilești) ${ }^{31}$ : община и одноименное село в жудеце Брэила, на левом берегу Дуная, т.е. в Княже-

${ }^{30}$ БАН, собр. В.Г. Дружинина, № 846, л. 195.

${ }^{31}$ Отметим, что метатеза слогов как в исконных, так и заимствованных топонимах является достаточно распространенным явлением во многих языках. 
стве Румыния (с 1859 по 1877 г. находившемся в вассальной зависимости от Турции), и два села в правобережной, собственно турецкой части: село в жудеце Констанца (рум. Constanţa) и небольшая деревня в жудеце Тульча ${ }^{32}$, см. рис. 1. Учитывая замечание Симеона Гаврилова о том, что скит находился «за Дунаем», т.е. на правом берегу реки, а также данные Показания... о расположении скита на турецкой стороне, левобережное Тикилешти, очевидно, следует исключить из списка потенциальных мест и попытаться выяснить, в котором из двух «турецких» сел мог быть интересующий нас филипповский скит.

Село Тикилешти в жудеце Констанца окружено несколькими липованскими поселениями. Практически рядом находится большое старообрядческое село Гиндэрешти (рум. Ghindărești; трад. рус. Новенькое, Новое село и др.), несколько дальше - общинный центр, город Хыршова (рум. Hârşova; трад. рус. Гuрсово), в котором также издавна проживают староверы. Однако, по официальным данным, в самом Тикилешти ни в начале XX в., ни сейчас староверов не было и нет: его населяют румыны и незначительное количество цыган ${ }^{33}$.

Еще одно Тикилешти - небольшая деревня, расположенная приблизительно на середине пути между Тульчей и Брэилой в нескольких километрах на запад от города Исакча (рум. Isaccea) и формально считающаяся одной из его частей. Приграничный город-крепость Исакча известен как один из придунайских населенных пунктов на территории Османской империи, в котором издавна жили староверы-некрасовцы ${ }^{34}$. Сведений же об этом Тикилешти и его истории удалось найти немного. В настоящее время он известен прежде всего как единственный действующий в Европе лепрозорий, открытый там, вероятно, в начале XX в. на базе бывшего монастыря ${ }^{35}$. В открытых интер-

${ }^{32}$ Cм. также: G. I. Lahovari, C. I. Brătianu, G. Tocilescu, Marele Dicţionar Geografic al Romîniei, Stab. grafic J. V. Socecŭ, București 1902, vol. V, c. 598.

${ }^{33}$ M.D. Ionescu, Dobrogea în pragul veacului al XX-lea. Geografia matematică, fisică, politică, economic şi militară, Atelierele Grafice I.V. Socecu, Bucureşti 1904, с. 417; Тикилешти (Констанца) // https://sr.wikipedia.org/wiki/Тикилешти_(Констанца) (15.05.2020).

${ }^{34}$ См., напр.: А.А. Пригарин, Русские старообрядцы на Дунае..., с. 95, 98-99 и др.

${ }^{35}$ В источниках приводятся разныедаты открытия лепрозория: 1875г. (Tichilești, Tulcea // https://en.wikipedia.org/wiki/Tichilești,_Tulcea (30.04.2020), 1877 г. (L.-D. Cizer, Toponimia judeţului Tulcea. Consideraţii sincronice şi diacronice, 
нет-источниках и научных публикациях приводятся две версии возникновения монастыря. Согласно одной из них, монастырь основан принцессой из рода Кантакузинов, которая, заболев проказой, поселилась в Тикилешти и повелела возвести там монастырь. Другая легенда гласит, что поселение основано русскими липованами, которые и построили монастырь, но потом стали промышлять разбоем, за что были пойманы и уничтожены. По мнению источников, наличие в прошлом монастыря на месте теперешней деревни-лепрозория не вызывает сомнений, так как больные проказой часто селились вблизи монастырей ${ }^{36}$. Рассказ о липованах-разбойниках едва ли соответствует действительности. Скорее всего, в народной памяти таким причудливым образом отложились события многочисленных русско-турецких войн ${ }^{37}$, в которых участвовали русские казаки и страдало местное население. В Исакче издавна жили казаки-некрасовцы (т.е. староверы), которые участвовали в военных действиях (обычно на стороне Турции) и которых местные жители могли называть липованами. В результате разбой и мародерство военного времени, русские, казаки и липоване в народном сознании без

Lumen Cizer, Iași 2012, p. 224), 1900 г., но чаще всего встречается указание на начало XX в. (без точного года), что, видимо, соответствует действительности, поскольку в общерумынских и региональных географических справочниках, изданных в начале XX в., информации о лепрозории в Тикилешти еще нет, см.: G. I. Lahovari, C.I. Brătianu, G. Tocilescu. Marele Dicționar..., c. 598; M. D. Ionescu, Dobrogea în pragul veacului..., c. 390.

${ }^{36}$ L. D. Cizer, Toponimia judeţului Tulcea..., c. 224-225; B. Comaroni, L. Kallai, Ultimul lazaret, „Ziua“, No 3579 (21 martie 2006), http://www.ziua.ro/display. php?data=2006-o3-21\&id=196153 (30.04.2020); и др. Благодарю Л. Барткене за помощь в переводе некоторых румынских источников.

37 Село Тикилешти фигурирует в русских военных мемуарах времен Крымской войны 1853-1856 гг., Русско-турецкой войны 1877-1878 гг. и Балканского театра военных действий Первой мировой войны (М.И. Богданович, Восточная война 1853-1856 годов, тип. Ф. Сущинскаго, Санкт-Петербург 1876, т. 1, с. 34 (второго счета); А. В. Верещагин, Дома и на войне. 1853-1881: Воспоминания и рассказы, Издание книжнаго склада В.А. Березовскаго, СанктПетербург 1886, с. 186; А. М. Зайончковский, Восточная война 1853-1856 г2. в связи с современной ей политической обстановкой, Экспедиция изготовления государственных бумаг, Санкт-Петербург 1913, т. II, ч. 1, с. 131; и др.), но упоминаний о русском населении и, тем более, существовании там монастыря (скита) в них нет. Монастырь в Тикилешти иногда встречается в болгарских мемуарах времен Первой мировой войны, напр.: През Добруджа. 14-а рота от 7-а пехота. Преславски полк. 1916-1917 2., Кооперативна печатница «Гутенберг», София 1918, с. 81. 
особых проблем трансформировались в приведенный выше сюжет. Однако упоминание русских староверов и их обители в связи с историей этой деревни заставило обратить на нее более пристальное внимание и продолжить поиски в румынской литературе.

Краткое упоминание о беспоповском липованском монастыре в Тикилешти удалось обнаружить в монографии Марина Ионеску Dobrogea în pragul veacului al XX-lea. Geografia matematică, fisică, politică, economic şi militară (1904). Он писал, что монастырь Тикилешти находится посередине дороги между Исакчей и Ракелу (рум. Rachelu). По его сведениям, это небольшая церковь, в которой когда-то было несколько липованских монахов-беспоповцев, а сейчас проживают 3 монахини-беспоповки из монастыря Киликуль (рум. Cilicul, CelicDere); они переселились в Тикилешти, поскольку не могли жить среди русских монахинь ${ }^{38}$. Ионеску также указал, что монастырская церковь была посвящена Вознесению Господню39, а сам скит, несмотря на то, что в начале XX в. в нем все еще жили три монахини, служил «скорее убежищем для грабителей, чем местом для молитвы» ${ }^{40}$.

Данные Ионеску о конфессиональной принадлежности монастыря и его насельников в начале XX в. противоречивы. Так, исследователь включил монастырь в список православных обителей, а не липованских (старообрядческих) церквей, но в то же время писал, что в нем проживали три монахини-беспоповки, переселившиеся из (православного) монастыря в Киликуле (ср.: «3 călugăriţe bespopove, plecate de la Cilicul, nemař putèndu trăi între călugăriţele rusóice» ${ }^{41}$; курсив мой - Н.М.). В таблице этноконфессионального состава населения региона он также отметил, что в начале XX в. в Тикилешти проживали только три липованина-беспоповца (в соседней Исакче, к примеру, кроме румын было 675 турок, 555 русских, 229 болгар, 129 греков,

${ }^{38} \mathrm{Cp} .:$ «Mănăstirea Tikilescǐ aşezată ìn fundul uneľ vǎǐ scurte spre Sud de cherhanaua Melentie, la 1/2 distanţă intre Isaccea şi Rakel. E o mică bisericuţă, care altă dată avea mai mulţi călugări lipoveni bespopovi, azi sunt 3 călugăriţe bespopove, plecate de la Cilicul, nemař putèndu trăi între călugăriţele rusóice» (M. D. Ionescu, Dobrogea în pragul veacului..., c. 390).

${ }^{39}$ M. D. Ionescu, Dobrogea în pragul veacului..., c. 651.

${ }^{40}$ Там же, с. 641.

${ }^{41}$ Там же, с. 390. 
31 липованин-беспоповец (хотя в данном случае речь идет, скорее всего, о беглопоповцах $)^{42}, 72$ татарина и т.д.) ${ }^{43}$.

В настоящий момент точная дата появления русских староверов-филипповцев в окрестностях Тикилешти неизвестна. Вероятнее всего они пришли «за Дунай» вскоре после окончания Крымской войны, так как в начале $1850-x$ гг., судя по всему, их там еще не было: Ионеску отметил, что в 1848-1850 гг. в Тикилешти жили 9 семей немцев ${ }^{44}$. По информации Георге Байсана, приведенной в электронном справочнике Dictionarul localitatilor din judetul Tulcea, в 1896 г. там была обычная «группа домов с 37 жителями рядом со старым монастырем монахов-беспоповцев», а в 1900 г. проживал 41 человек45; к сожалению, этноконфессиональная принадлежность населения в обоих случаях не уточнена. Сложно сказать, чем объясняется столь значительная разница в количестве населения у Ионеску и Байсана, поскольку Байсан не указал список своих источников.

Сведения Ионеску о беспоповском монастыре в Тикилешти повторены в монографии Сорин-Кристиан Айлинкэй ${ }^{46}$, а также геоисторическом исследовании археологических и исторических памятников на территории Исакчи ${ }^{47}$, но при этом никогда не приводились в научной литературе по истории старообрядчества в Румынии.

$4^{2}$ Очевидно, Ионеску не различал беспоповцев и беглопоповцев и причислял последних к беспоповцам: термин беглопоповцы в его монографии не используется, а известные беглопоповские общины в селах Слава Черкезе (рум. Slava Cercheză) и Сарикёй (рум. Sarichioi), видимо, «скрываются» под определением «беспоповцы» (M.D. Ionescu, Dobrogea în pragul veacului..., c. 653). Современную географию расселения и конфессиональную структуру липован Румынии см.: Radu Bobică, Dicționar de termeni și concepte teologice, ePublishers \& Editura Coresi 2020, c. 203-204; F. Ipatiov, Ruşii-lipoveni din România: studiu de geografie umana, Presa Universitară Clujeană, Cluj 2001.

${ }^{43}$ M.D. Ionescu, Dobrogea în pragul veacului..., c. 381.

44 Там же, с. 345.

${ }^{45}$ Gh. Baisan, Dictionarul localitatilor din judetul Tulcea, 2017, vol. N-Z, https:// tulcealibrary.ro/wp-content/uploads/2017/02/T-Z.pdf (15.05.2020).

${ }^{46}$ S.-Cr. Ailincăi, Începuturile epocii fierului în Dobrogea. Cercetările arheologice de la Revărsarea, Isaccea, judeţul Tulcea, Tulcea 2013, c. 13-14.

${ }^{47}$ Cp.: «Se pare ca la Tichilesti in trecut a existat un schit al calugarilor lipoveni bespopovi care insa, la inceputul sec. XX era aproare parasit, aici traind doar 3 calugari». Studiu geoistoric. Situri şi monumente arheologice şi istorice în teritoriul administrativ al oraşului Isaccea, jud. Tulcea, Tulcea County Council Eco-Museal Research Institute 2000, c. 5, https://www.isaccea.ro/images/2018/ urbanism/pug/studiugeoistoric.pdf (15.05.2020); курсив мой - Н. М. Кстати, здесь монастырское поселение названо скитом. 
Таким образом, обращение к румынской географической и историко-краеведческой литературе показало, что данные о Кителештском филипповском ските, обнаруженные в собственно старообрядческих рукописных памятниках, находят подтверждение в румынских источниках. Кроме того, как было показано выше, в них имеются новые данные (напр., посвящение монастыря, состояние построек и др.), которые не были известны по филипповским текстам.

\section{ВЫВОДЫ И ПЕРСПЕКТИВЫ ДАЛЬНЕЙШИХ ИССЛЕДОВАНИЙ}

Как показало проведенное исследование, осторожные упоминания, иногда встречаемые в литературе, о присутствии филипповцев-беспоповцев на территории современной Румынии, могут иметь двоякую причину:

1) терминологическая омонимия (Филипповць-беспоповцы и филипповцы, филипоны/пилипоны (филиппоны), филипповане, липоване поповцы или даже староверы вообще) и, как следствие, ошибочная интерпретация данных первоисточников и причисление упоминаемых там филипповцев-поповцев к филипповцам-беспоповцам;

2) отсутствие (незнание) конкретной информации у того или иного исследователя и скорее предположение о возможном проживании филипповцев-беспоповцев, чем констатация реальных фактов.

Внимательное изучение филипповских рукописных источников и данные румынских исследований и справочников позволило выявить по меньшей мере один филипповский беспоповский центр (обитель), существовавший в северной (ныне румынской) части Добруджи во второй половине XIX в. Это небольшой филипповский скит в окрестностях Исакчи на правом берегу Дуная. На основании имеющихся в настоящий момент данных можно утверждать следующее:

1) Приведенные выше материалы позволяют надежно отождествлять «Кителештскую пустыню», упоминаемую в филипповских рукописях, с беспоповским монастырем в дер. Тикилешти, расположенной на правом берегу Дуная в жудеце Тульча. Причину метатезы первых двух слогов в названии населенного пункта указать затруднительно: это может быть связано как 
с обычной меной для облегчения произношения заимствованных слов, так и с попыткой конспирации. Но на данном этапе исследования наблюдается четкое разграничение употребления: Кителешт - в старообрядческих филипповских источниках и официальное Тикилетши - в русской мемуаристике и военных документах;

2) На момент написания статьи нам известны имена 12 насельников Кителештского филипповского скита, некоторые из них надежно идентифицированы (это известные деятели филипповского согласия);

3) Кителештский скит был посвящен Вознесению Господню;

4) Согласно сведениям старообрядческих рукописных памятников, филипповский скит в Тикилешти просуществовал до середины (или конца) 1870-х гг.: Симеон Гаврилов уехал в 1874 г.; Леонтий Гаврилов покинул «скит Кителештъ» в мае 1875 г.; инок Макарий или постриг, или получил благословение на по́стриг Варсанофия от инока Иова, «п8стыножителя скита Кительшты въ Т8рцыи», в декабре 1875 г. Сам Макарий пробыл в Тикилешти около полугода и вернулся в Россию, видимо, в первой половине 1876 г., и, как пишет Фролов, по возвращении в Москву присоединился «къ еретик8 и ш̈ст8пник8» Павлу Прусскому, а в 1877 и 1878 гг. хотел покаяться и вернуться в филипповское согласие. Никакой информации о пребывании филипповцев в окрестностях Тикилешти в $1880-x$ гг. и позже в старообрядческих памятниках письменности найти не удалось.

Этому выводу не противоречат и румынские источники. Как указывалось выше, в начале XX в. монастырь был заброшен, а большинство его построек пришли в негодность. Мужская обитель к тому времени перестала существовать и в полуразрушенных строениях нашли пристанище три монахини-липованки беспоповского согласия, которые, видимо, по вероисповедным причинам не могли жить в соседнем монастыре в Киликуле вместе с русскими православными монахинями. Несколькими годами позже в Тикилешти было основано поселение для больных проказой.

На данном этапе изучения сложно сказать, что послужило причиной ухода филипповцев из Тикилештской обители. Это могло быть как чувство опасности перед очередной приближавшейся русско-турецкой войной (1877-1878 гг.) и, как следствие, добровольный исход, поскольку скит находился в нескольких 
километрах от границы, в непосредственной близости от Исакчи, одного из турецких приграничных оборонительных городовкрепостей, так и какие-либо внешние административные обстоятельства, вынудившие покинуть обжитые места. Прояснить ситуацию могло бы знакомство как с материалами о военных действиях у крепости Исакча в румынских, турецких и, частично, российских архивах, так и документами по организации тикилештского лепрозория. Точная дата основания обители также неизвестна. Можно лишь предполагать, что скит возник во второй половине 1850-х гг., после окончания Крымской войны. Не выяснены также конкретные причины и обстоятельства, вынудившие инока Марка и его единомышленников покинуть пределы Российской империи и искать пристанище за границей, в Турции. Очевидно, новые старообрядцы-мигранты должны были каким-то образом легализовать свое пребывание в чужой стране: получить разрешение местных (турецких) светских и духовных властей на организацию монашеского поселения и открытие собственной моленной (как было в случае с отцом Афанасием, когда он хотел основать монастырь в Киликуле ${ }^{48}$, и др.). Даже если поселение возникло стихийно, весть о нем среди российских филипповцев распространилась очень быстро, а сам скит, видимо, стал авторитетным центром: в 1870-х гг. в нем побывали такие видные деятели филипповского согласия, как Симеон Гаврилов, Леонтий Гаврилов, Варсонофий Донской и др. Поэтому следующим шагом в изучении истории этого неизвестного ранее беспоповского филипповского центра должна стать как работа в румынских и, возможно, турецких архивах, так и дальнейшие поиски информации о нем в собственно филипповских источниках.

\section{СПИСОК СОКРАЩЕНИЙ}

БАН - Библиотека Российской Академии наук, Санкт-Петербург БВАНЛ - Библиотека им. Врублевских Академии наук Литвы, Вильнюс ИРЛИ - Институт русской литературы (Пушкинский Дом) Российской Академии наук, Санкт-Петербург

РГБ - Российская государственная библиотека, Москва РГИА - Российский государственный исторический архив, Санкт-Петербург

${ }^{48}$ См.: П. Сырку, Наши раскольники в Румынии..., с. 697-698; M.D. Ionescu, Dobrogea în pragul veacului..., c. 407-408. 


\section{СПИСОК ИСПОЛЬЗОВАННЫХ РУКОПИСНЫХ ИСТОЧНИКОВ}

БАН, собр. Г.В. Дружинина (ф. 19), № 846

БАН, собр. Ф.А. Каликина (ф. 67), № 107

БАН, собр. Ф.А. Каликина (Ф. 67), № 109

БВАНЛ, F19-331

ИРЛИ, Р-IV, собр. Ф.А. Каликина, № 52

РГБ, собр. Братства Петра митрополита (ф. 579), № 58

РГИА, ф. 796, оп. 46, д. 160

\section{REFERENCES}

[Feofilakt (Lopatinskiy)]. Oblicheniye nepravdy raskol'nicheskoy. Moskva: Sinodal'naya tipografiya, 1745 [Феофилакт (Лопатинский)]. Обличение неправды раскольнической. Москва: Синодальная типография, 1745].

[Kulczynski, Ignatium]. Specimen Ecclesiae Ruthenicae: ab origine susceptae fidei ad nostra usque tempora in suis capitibus seu primatibus Russiae cum S. Sede Apostolica Romana semper unitae per Ignatium Kulczynski. Parisiis: Lethielleux, 1859.

[Nadezhdin, Nikolay Ivanovich]. "O zagranichnykh raskol'nikakh, Nadezhdina (1846)." Sbornik pravinel'stvennykh svedeniy o raskol'nikakh. Vyp. 1. Comp. Kel'siyev, Vasiliy Ivanovich. London: Trübner \& Co , 1860. 75-137 [Надеждин, Николай Иванович]. “О заграничных раскольниках, Надеждина (1846).” Сборник правительственных сведений о раскольниках. Вып. 1. Сост. Кельсиев, Василий Иванович. Лондон: Trübner \& $C^{\circ}, 1860.75^{-137] .}$

Ailincăi, Sorin-Cristian. Începuturile epocii fierului în Dobrogea. Cercetările arheologice de la Revărsarea, Isaccea, judeţul Tulcea. Tulcea, 2013.

Baisan, Gheorghe. Dictionarul localitatilor din judetul Tulcea. Vol. N-Z. 2017 <https://tulcealibrary.ro/wp-content/uploads/2017/o2/T-Z.pdf>

Bezgodov, Aleksey Aleksandrovich. "Starovery-bespopovtsy Pridunav'ya (kratkiy obzor soglasiy).” Lipovane. I. Odessa, 2004. 60-63 [Безгодов, Алексей Александрович. “Староверы-беспоповцы Придунавья (краткий обзор согласий).” Липоване, І. Одесса, 2004. 60-63].

Bibliografiya rabot po nazvaniyam i samonazvaniyam staroobryadtsev severozapadnogo Prichernomor'ya. 2016 <http://eurasianphonology.info/static/ groups/biblio.html> [Библиография работ по названиям и самоназваниям старообрядцев северо-западного Причерноморья. $2016<\mathrm{http} / /$ eurasianphonology.info/static/groups/biblio.html> ]

Bobică, Radu. Dicționar de termeni și concepte teologice. ePublishers \& Editura Coresi, 2020.

Bogdanovich, Modest Ivanovich. Vostochnaya voyna 1853-1856 godov. T. 1. Sankt-Peterburg: tip. F. Sushchinskago, 1876 [Богданович, Модест Иванович. Восточная война 1853-1856 годов. Т. 1. Санкт-Петербург: тип. Ф. Сущинскаго, 1876].

Budaragin, Vladimir Pavlovich. "«A krasok i tushi s knigami poshli...» (Perepiska severodvinskikh krest'yan-staroobryadtsev XX v.).” Puti $i$ mirazhi russkoy kul'tury. Ed. Bagno, Vsevolod Evgen'yevich. Sankt-Peterburg: Severo-Za- 


\section{К ВОПРОСУ О СТАРОВЕРАХ-ФИЛИППОВЦАХ...}

pad, 1994. 364-382 [Бударагин, Владимир Павлович. “"А красок и туши с книгами пошли...» (Переписка северодвинских крестьян-старообрядцев XX в.).” Пути и миражи русской культуры. Отв. ред. Багно, Всеволод Евгеньевич. Санкт-Петербург: Северо-Запад, 1994. 364-382].

Chistov, Kirill Vasil'yevich. "Legenda o Belovod'ye." Voprosy literatury i narodnogo tvorchestva: sb. st. (Trudy Karel'skogo filiala AN SSSR, 35). Eds. Evseyev, Viktor Yakovlevich and Karkhu, Eyno Genrikhovich. Petrozavodsk: Karel'skoye knizhnoye izd-vo, 1962. 116-181 [Чистов, Кирилл Васильевич. “Легенда о Беловодье.” Вопросы литературы и народного творчества: сб. ст. (Труды Карельского филиала АН СССР, 35). Отв. ред. Евсеев, Виктор Яковлевич и Карху, Эйно Генрихович. Петрозаводск: Карельское книжное изд-во, 1962. 116-181].

Cizer, Laura-Diana. Toponimia judeţului Tulcea. Consideraţii sincronice şi diacronice. Iași: Lumen, 2012.

Comaroni, Bogdan, Kallai, Laszlo. "Ultimul lazaret." Ziua, No 3579 (21 martie 2006) <http://www.ziua.ro/display.php?data=2006-03-21\&id=196153>

Dovgyallo, Dmitriy Ivanovich. "Mogilevskaya starina. K istorii Vetki. Dokument 1690 goda." Mogilevskaya starina: Sbornik statey "Mogilevskikh gubernskikh vedomostey", 1: 1898 i $1899 \mathrm{gg}$. Ed. Romanov, Yevdokim Romanovich. Mogilev Gubernskiy: Tipografiya Gubernskago pravleniya, 1900. 1-5 (10-go scheta) [Довгялло, Дмитрий Иванович. "Могилевская старина. К истории Ветки. Документ 1690 года.” Могилевская старина: Сборник статей «Могилевских губернских ведомостей», 1: 1898 и 1899 га. Ред. Романов, Евдоким Романович. Могилев Губернский: Типография Губернскаго правления, 1900. 1-5 (10-го счета)].

Gorbatskiy, Andrey Aleksandrovich. Staroobryadchestvo na belorusskikh zemlyakh. Brest, 2004 [Горбацкий, Андрей Александрович. Старообрядчество на белорусских землях. Брест, 2004].

Gorbunov, Yuriy Evgen'yevich. "K voprosu o proiskhozhdenii nazvaniya «lipovane»." Arkheologiya ta etnologiya Skhidnoï Guropi: materiali $i$ doslidzhennya. Odesa: Astroprint, 2000. 135-144 [Горбунов, Юрий Евгеньевич. "К вопросу о происхождении названия «липоване»." Археологія та етнологія Східної Європи: матеріали і дослідження. Одеса: Астропринт, 200о. 135-144].

Ignatova, Tat'yana Viktorovna. " $\mathrm{K}$ istorii moskovskogo filippovskogo tsentra Bratskiy dvor vo vtoroy polovine XIX - nachale XX vv. (novye dokumenty iz fondov TsIAM).” Staroobryadchestvo: istoriya, kul'tura, sovremennost', 13. Moskva, 2009. 44-62 [Игнатова, Татьяна Викторовна. “К истории московского филипповского центра Братский двор во второй половине XIX - начале XX вв. (новые документы из фондов ЦИАМ).” Старообрядчество: история, культура, современность, 13. Москва, 2009. 44-62].

Ionescu-[Dobrogianu], Marin. Dobrogea în pragul veacului al XX-lea. Geografia matematică, fisică, politică, economic şi militară. Bucureşti: Atelierele Grafice I.V. Socecŭ, 1904.

Ipatiov, Filip. Ruşii-lipoveni din România: studiu de geografie umana. Cluj: Presa Universitară Clujeană, 2001.

Iwaniec, Eugeniusz. $Z$ dziejów staroobrzędowców na ziemiach polskich XVII$X X w$. Warszawa: Państwowe Wydawnictwo Naukowe, 1977.

Jakubowski, Wiktor. "Z historii kolonii staroobrzędowców rosyjskch na Mazurach." Slavia Orientalis 1961, no. X(1): 81-103. 
Kirile, Feodor Ivanovich. “O genezise etnonima «Russkiye lipovane».” Staroobryadchestvo. Istoriya. Kul'tura. Sovremennost'. Materialy. T. 2. Comp. by Osipov, Viktor Ivanovich, et al., Moskva, 2007. 104-117 [Кирилэ, Феодор Иванович. “О генезисе этнонима «Русские липоване»." Старообрядчество. История. Культура. Современность. Материалы. Т. 2. Сост. Осипов, Виктор Иванович, и др., Москва, 2007. 104-117].

Kozhurin, Kirill Yakovlevich. Dukhovnye uchitelya sokrovennoy Rusi. SanktPeterburg: Piter, 2007 [Кожурин, Кирилл Яковлевич. Духовные учителя сокровенной Руси. Санкт-Петербург: Питер, 2007].

Lahovari, George Ioan, Brătianu, Constantin I., Tocilescu, Grigore. Marele Dicționar Geografic al Romîniei. Vol. V. București: Stab. grafic J.V. Socecŭ, 1902.

Lipinskaya, Viktoriya Anatol'yevna. "Etnonimy i konfessionimy russkogo naseleniya v Rumynii.” Etnograficheskoye obozreniye, 1998, no. 5: 44-58 [Липинская, Виктория Анатольевна. “Этнонимы и конфессионимы русского населения в Румынии.” Этнографическое обозрение, 1998, no. 5: 44-58].

Morozova, Nadezhda. "Filippovskoye rodosloviye iz rukopisnogo sobraniya Biblioteki im. Vrublevskikh Akademii nauk Litvy: istochnikovedcheskiy analiz." Izvestiya Ural'skogo federal'nogo universiteta. Ser. 2: Gumanitarnyye nauki 2020, t. 22, no. 3 (200): 72-88 <DOI 10.15826/izv2.2020.22.3.045> [Морозова, Надежда. “Филипповское родословие из рукописного собрания Библиотеки им. Врублевских Академии наук Литвы: источниковедческий анализ." Известия Уральского федерального университета. Сер. 2: Гуманитарные науки 2020, т. 22, по. 3 (200): 72-88 <DOI 10.15826/ izv2.2020.22.3.045>].

Morozova, Nadezhda. "Rukopisnyy sbornik sobornykh postanovleniy i drugikh sochineniy filippovtsev v sobranii Biblioteki im. Vrublevskikh AN Litvy.” Slavistica Vilnensis 2019, no. 64(1). 87-103, <https://www.journals.vu.lt/slavisticavilnensis/article/view/15018> [Морозова, Надежда. "Рукописный сборник соборных постановлений и других сочинений филипповцев в собрании Библиотеки им. Врублевских АН Литвы.” Slavistica Vilnensis 2019, no. 64(1). 87-103, <https://www.journals.vu.lt/slavistica-vilnensis/article/view/15018>].

Munteanu, Ioan. Monografia rușilor lipoveni din Brăila. Pescuitul, activitate tradițională. Brăila: Proilavia, 2015.

Pastuszewski Stefan. Przegląd źródeł i opracowań do badań staroprawosławia. Bydgoszcz: Instytut Wydawniczy "Świadectwo", 2016.

Polnoye sobraniye sochineniy Nikol'skago yedinovercheskago monastyrya nastoyatelya arkhimandrita Pavla. T. 1. Moskva: Tipografiya E. Lissnera i Yu. Romana, 1897 [Полное собрание сочинений Никольскаго единоверческаго монастыря настоятеля архимандрита Павла. Т. 1. Москва: Типография Э. Лисснера и Ю. Романа, 1897].

Potashenko, Grigoriy. Staroveriye v Litve: Vtoraya polovina XVII - nachalo XIXvv. Issledovaniya, dokumenty, materialy. Vil'nyus: Aidai, 2006 [Поташенко, Григорий. Староверие в Литве: Вторая половина XVII - начало XIX вв. Исследования, документы, материалы. Вильнюс: Aidai, 2006].

Prez Dobrudzha. 14-a rota ot 7-a pekhota. Preslavski polk. 1916-1917 g. Sofiya: Kooperativna pechatnitsa "Gutenberg”, 1918 [През Добруджа. 14-а рота от 7-а пехота. Преславски полк. 1916-1917а. София: Кооперативна печатница "Гутенберг", 1918]. 


\section{К ВОПРОСУ О СТАРОВЕРАХ-ФИЛИППОВЦАХ...}

Prigarin, Aleksandr Anatol'yevich. Russkiye staroobryadtsy na Dunaye. Formirovaniye etnokonfessional'noy obshchnosti $v$ kontse XVIII - pervoy polovine $X I X v v$. Odessa-Izmail-Moskva: Smil - Arkheodoksiya, 2010 [Пригарин, Александр Анатольевич. Русские старообрядцы на Дунае. Формирование этноконфессиональной общности в конце XVIII - первой половине XIX вв. Одесса-Измаил-Москва: Смил - Археодоксия, 2010].

Rykov, Yuriy Dmitriyevich. "Yaroslavskiy spisok «Puteshestvennika» Marka Topozerskogo." Knizhnaya kul'tura Yaroslavskogo kraya - 2014: sbornik statey i materialov. Ed. Abrosimova, Natal'ya Vladimirovna. Yaroslavl': Izdatel'skoe byuro "VND”, 2015. 11-57 [Рыков, Юрий Дмитриевич. “Ярославский список «Путешественника» Марка Топозерского.” Книжная культура Ярославского края - 2014: сборник статей и материалов. Ред. Абросимова, Наталья Владимировна. Ярославль: Издательское бюро «ВНД», 2015. 1157].

Shchipin, Vladimir Igorevich. Staroobryadchestvo v verkhnem techenii Severnoy Dviny. Moskva: Labirint, 2003 [Щипин, Владимир Игоревич. Старообрядчество в верхнем течении Северной Двины. Москва: Лабиринт, 2003].

Shchipin, Vladimir Igorevich. "Zhizn' i trudy startsa Simeona Severodvinskogo." Zhitiye Gerasima Voshchikova: iz istorii filippovskogo soglasiya (Sochineniye startsa Simeona Gavrilova). Publ., preface and comments by Shchipin, Vladimir Igorevich. Moskva: Staroobryadcheskoe izdatel'stvo “Tretiy Rim”, 2010. 3-21 [Щипин, Владимир Игоревич. “Жизнь и труды старца Симеона Северодвинского.” Житие Герасима Вощцикова: из истории филипповского согласия (Сочинение старца Симеона Гаврилова). Публ., предисл. и коммент. Щипин, Владимир Игоревич. Москва: Старообрядческое издательство «Третий Рим», 2010. 3-21].

"Sostoyanie staroobryadcheskago raskola i pravoslavnoy missii sredi nego za $1909 \mathrm{~g} . "$ Polotskiye yeparkhial'nyye vedomosti 1911, nо. 17: 342-350 ["Состояние старообрядческаго раскола и православной миссии среди него за 1909 г.” Полоцкие епархиальные ведомости 1911, по. 17: 342-350].

Studiu geoistoric. Situri şi monumente arheologice şi istorice în teritoriul administrativ al oraşului Isaccea, jud. Tulcea, Tulcea County Council - Eco-Museal Research Institute, 2000 <https://www.isaccea.ro/images/2018/urbanism/pug/ studiugeoistoric.pdf>

Syrku, Polikhroniy. "Nashi raskol'niki v Rumynii i otnosheniye k nim rumynskago pravitel'stva." Khristianskoye chteniye 1878, no. 5-6: 663-705 [Сырку, Полихроний. "Наши раскольники в Румынии и отношение к ним румынскаго правительства,” Христианское чтение 1878, no. 5-6: 663-705].

Vereshchagin, Aleksandr Vasil'yevich. Doma i na voyne. 1853-1881: Vospominaniya i rasskazy. Sankt-Peterburg: Izdaniye knizhnago sklada V.A. Berezovskago, 1886 [Верещагин, Александр Васильевич. Дома и на войне. 1853-1881: Воспоминания и рассказы. Санкт-Петербург: Издание книжнаго склада В.А. Березовскаго, 1886].

Volkov, Vasiliy. Svedeniya o nachale, rasprostranenii $i$ razdelenii raskola i o raskole $v$ Vitebskoy gubernii. Vitebsk: V tipografii gubernskago pravleniya, 1866 [Волков, Василий. Сведения о начале, распространении и разделении раскола и орасколе в Витебской губернии. Витебск: В типографии губернскаго правления, 1866]. 
Yukhimenko, Yelena Mikhaylovna. "«Izyskanie o inocheskom postrizhenii» (Filippovskoe sochinenie 60-kh gg. XIX v.).” Traditsii russkoy dukhovnoy kul'tury $v$ pamyatnikah XVI-XX v. (Arkheografiya $i$ istochnikovedenie Sibiri, 37). Ed. Elert, Aleksandr Khristianovich. Novosibirsk, 2018. 168-178 [Юхименко, Елена Михайловна. “«Изыскание о иноческом пострижении» (Филипповское сочинение 60-х гг. XIX в.).” Традиции русской духовной культуры в памятниках XVI-XX в. (Археография и источниковедение Сибири, 37). Отв. ред. Элерт, Александр Христианович. Новосибирск, 2018. 168-178].

Yukhimenko, Yelena Mikhaylovna. "K voprosu o knizhnoy osnove staroobryadcheskoy kul'tury. Neizvestnyy filippovskiy nachetchik starets Sergiy Kokshen'gskiy.” Yazyk, kniga i tradicionnaya kul'tura pozdnego russkogo Srednevekov'ya $v$ nauke, muzeynoy i bibliotechnoy rabote: trudy IV Mezhdunarodnoy nauchnoy konferentsii (Mir staroobryadchestva, 10). Comp. by Belyankin, Yuriy Sergeyevich, Vorontsova, Yelena Vladimirovna and Litvina, Natal'ya Viktorovna. Moskva: Izd-vo Moskovskogo universiteta, 2019. 604-615 [Юхименко, Елена Михайловна. "К вопросу о книжной основе старообрядческой культуры. Неизвестный филипповский начетчик старец Сергий Кокшеньгский.” Язык, книга и традиционная культура позднего русского Средневековья в науке, музейной и библиотечной работе: труды IV Международной научной конференции (Mup старообрядчества, 10). Сост. Белянкин, Юрий Сергеевич, Воронцова, Елена Владимировна, Литвина, Наталья Викторовна. Москва: Изд-во Московского университета, 2019. 604-615].

Zayonchkovskiy, Andrey Medardovich. Vostochnaya voyna 1853-1856 gg. v svyazi s souremennoy ey politicheskoy obstanovkoy. T. II, ch. 1. Sankt-Peterburg: Ekspeditsiya izgotovleniya gosudarstvennykh bumag, 1913 [Зайончковский, Андрей Медардович. Восточная война 1853-1856 г2. в связи с современной ей политической обстановкой. T. II, ч. 1. Санкт-Петербург: Экспедиция изготовления государственных бумаг, 1913].

К странице 31:

Рис. 1: Фрагмент карты Северной Добруджи (Румыния). Деревня Тикилешти (pyм. Tichilești) в жудеце Тульча, где находился филипповский скит, подчеркнута. Источник: Europos keliu atlasas. 1:800 oоo. Hallwag International, 2011, c. 233. 


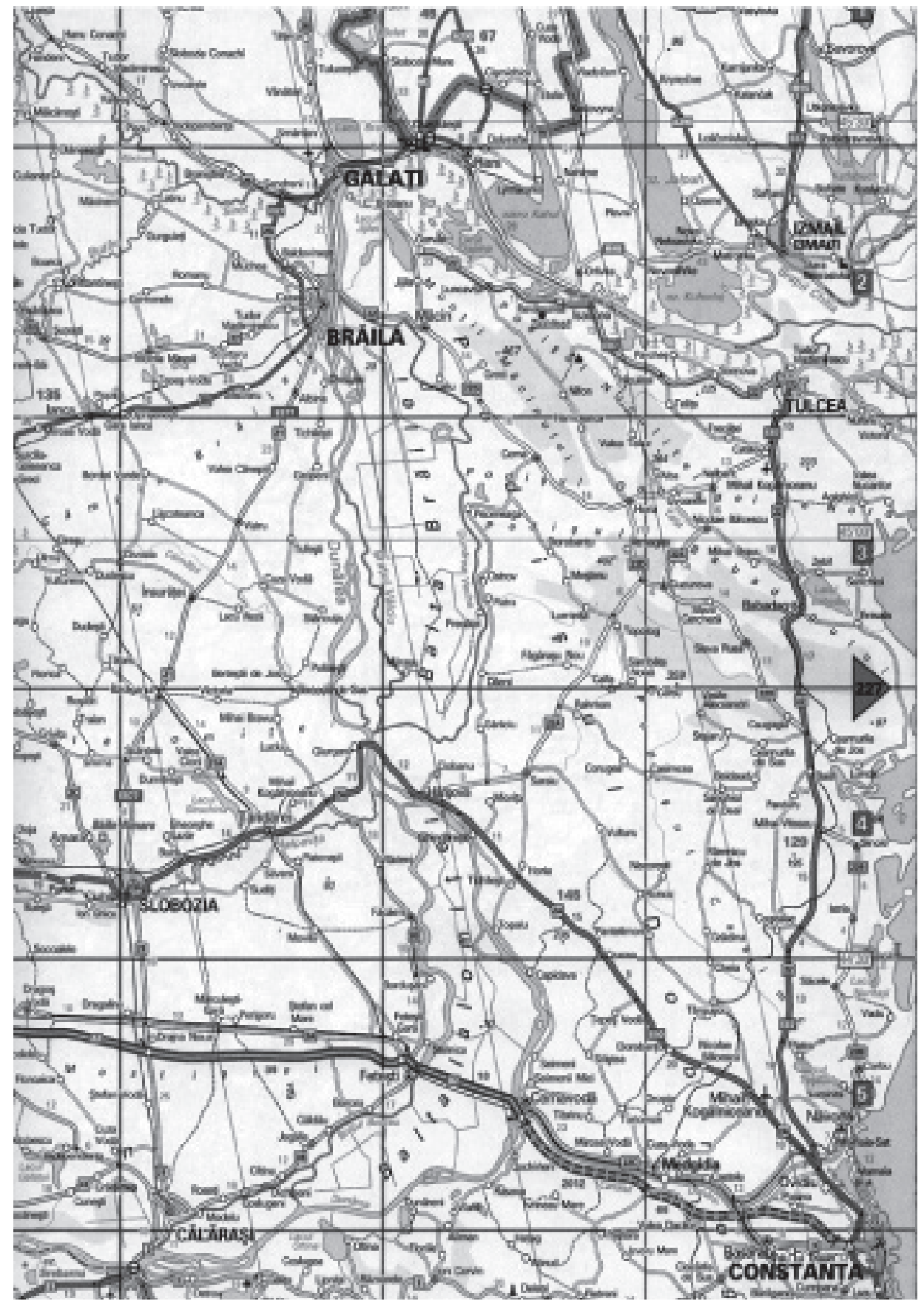

